\title{
"What good are all these divisions in Islam?". Everyday Islam and normative discourses in Daghestan
}

\author{
Iwona Kaliszewska ${ }^{1}$
}

Published online: 5 June 2019

(C) The Author(s) 2019

\begin{abstract}
Republic of Daghestan is the most multiethnic and troublesome region in the Russian Federation. The social, religious and political landscape of this republic has radically changed over the last two decades. Daghestan appears in academic and analytical papers mostly in relation to terrorism or security issues. The everyday religiosity is, for the most part, out of the picture. This paper aims to fill the gap by focusing on everyday Islam in this republic. It is intended as a contribution to the anthropology of Islam and post-Soviet area studies. What can we learn about the social changes in the given setting if we re-focus our attention from religious figures, organizations and institutions and drift towards the everyday perceptions and experiences of ordinary Muslims, towards religiosity as embedded in everyday life but not within a clearly identifiable group? Religious life in Daghestan is usually viewed through official categories of "traditional Islam" and "non-traditional Islam", the former equated with "Sufism", the latter with "Wahhabism". As will be clear from this paper these theology driven qualifiers are usually used in a secular sense, with no clear religious content attached to them. However, as a part of powerful discourses they affect religious life of ordinary Muslims. How do they relate to these categories? In my paper I show how attitudes towards Salafi-oriented Muslims changed in Daghestan between 2007 and 2017: they drifted from being informed by official categories to being informed by everyday experiences. I will also show how and in what contexts Daghestani Muslims engaged and played with the categories, bringing in some comparisons with late-Socialism. Eventually, I will engage with the concept of "everyday Islam", its potentials and limitations as an analytical category used for the analysis of social life in the North Caucasus where an organized religious and political activity is limited and where the clearly identifiable groups are not those that are behind the most vital social changes. The paper is based on ethnographic fieldwork conducted between 2007 and 2017 among Daghestani Muslims in Makhachkala and beyond.
\end{abstract}

Iwona Kaliszewska

i.kaliszewska@uw.edu.pl

1 Institute of Ethnology and Cultural Anthropology, Univeristy of Warsaw, Warszawa, Poland 
Keywords Islam in Russia · North Caucasus · Everyday Islam · Salafism · Wahhabism • State violence $\cdot$ Daghestan

\section{Introduction}

Daghestan is the most multiethnic and the biggest republic in the North Caucasus. The social, political and religious landscape of this republic has radically changed over the last two decades. In the analytical papers the changes are usually reflected in numbers. Numbers of victims of state and anti-state violence, numbers of adherents of "Wahhabism" and "traditional Islam" and more recently, numbers of ISIS recruits from the region. The everyday changes in religiosity and their character are, for the most part, out of the picture. This paper aims to fill the gap by focusing on the changes from the bottom-up perspective. It is intended as a contribution to the anthropology of Islam and post-USSR area studies.

As I immersed myself in the world of Daghestani Muslims I looked at it through official categories of "traditional Islam" and "non-traditional Islam", the former equated with "Sufism", the latter with "Wahhabism". I was admittedly dismayed when, initially, in 2007 I did not meet anybody who identified as a "Wahhabi" while at the same time I heard countless narratives and comments about "them". Most of my interviewees would say about themselves: "We're Muslims - simply Muslims." Initially, I believed that, as I ventured deeper into the field and won the trust of my informants, I would reach identities and divisions that remained hidden, mainly for reasons of security. As time went by, I succeeded in tracking down self-declared Wahhabis, who preferred to use the term "one God's people (jedinobozhniki)". I had met murids (initiates) of the Daghestani shaykh Said Efendi ${ }^{1}$ and I met Muslim "clerics" who introduced me to the world of madhhabs, in particular to the Shafi'i school, the most popular madhhab in Dagestan.

Throughout the research, out of people who called themselves observant Muslims ${ }^{2}$ around $10-15 \%$ would identify as jedinobozhniki - for reasons of clarity I will call them here Salafi-oriented Muslims. Around $10 \%$ would be affiliated with Sufi brotherhoods. ${ }^{3}$ The remaining 75-80\% would identify as "simply Muslims" or "observant Muslims" (sobludayushchiye musulmaniye) and did not adhere to any madhhab, some did not even know about their existence. In trying to estimate the numbers and categories, I realized, that despite assuming an anthropological perspective and trying to stay far from essentializing and attributing distinctive features to "Wahhabis" or murids of the local shaykhs, I was indirectly doing so. I failed to realize that focusing on clearly identifiable groups or organizations, though methodologically sound, is not the best research approach in this context.

What can we learn about the social changes in the given setting if we re-focus our attention from the alleged social divisions, religious figures, organizations and institutions and drift towards the everyday perceptions and experiences of ordinary Muslims,

\footnotetext{
${ }^{1}$ Also known as Chirkiesky after the name of his home town.

${ }^{2}$ Being an observant Muslim certainly could mean a different thing to a different person - but for most it included a daily prayer, fasting and giving sadaka.

${ }^{3}$ These numbers are hard to establish. The rough estimates of $10-15 \%$ are based on conversations with authoritative people (imams, DUMD officials and representatives of the state). The results of the survey conduced in 2015 by Ministry of Youth Affairs show that 11.5 young people consider Salafism a proper religion for Daghestan (Yarlykapov 2019).
} 
towards religiosity as embedded in everyday life but not within a clearly identifiable group? What is their perception of these theology driven categories and how are they related to their everyday experiences?

Through the practice of co-habitation with several local families I take a closer look at the everyday life of Daghestani Muslims between 2007 and 2017. In my paper I show how attitudes towards Salafi-oriented Muslims changed in Daghestan between 2007 and 2017: they drifted from being informed by official categories (that started losing meaning when people immersed themselves in religious practice) to being informed by everyday experiences. By official categories I understand theologyderived qualifiers such as "Wahhabism", "Sufism", "traditional Islam", "Salafism", which as I will demonstrate were usually used in a secular sense. I will also show that gradually Muslims in Daghestan stopped using the official categories to emically identify themselves, while they still engaged and played with them. I will also discuss the possible reasons behind that shift. In the background of the locally grounded social changes I will engage with the term "everyday Islam" as applied to the post-Soviet and in particular the North Caucasian reality.

\section{Methodology}

This study is based on ethnographic fieldwork I conducted between 2007 and 2017 among Daghestani Muslims. Starting in one of the neighborhoods in Makhachkala, I followed my interlocutors in their visits to relatives in the mountains and in the lowlands. In this way, my research, initially confined to one neighborhood, eventually expanded into a multi-sided ethnography (Marcus 1995; Hannerz 2012). Vicini (2017: 97) notes that "while cohabitation and the sharing of intimacy have always been the core and founding principles of anthropological inquiry, they have not often been used in anthropological studies on Islam". Through cohabitation and participation in daily activities of the Nur brotherhood he was able to focus on their experiences and bodily dispositions and point to experiential and inter-individual nature of Muslim practices and moralities. This observation would not, I believe, be possible, if he focused solely on interviews. For me cohabitation was not a matter of choice. Bearing in mind the unstable situation in the republic and suspicions that my stay there raised, the only way to conduct ethnographic research was to live with families. My hosts also warned me against hotels, which they considered unsafe and "not a proper place for a woman". 4 As a result, during each of my 2-3-month long stays ${ }^{5}$ I lived with my informants and their families, sharing rooms and everyday chores, cooking and eating together, preparing parties, participating in family gatherings. I also followed them to mosques, Islamic stores and other places they frequented. I looked at the experiences of being (or becoming) an observant Muslim, their struggles to communicate their new experience to family members. I listened to questions that were asked and emotional comments

\footnotetext{
${ }^{4}$ While they might have exaggerated, in a town not frequented by tourists, a single woman staying alone in a hotel room especially until 2011-2, was perceived as an "accessible woman", which at least potentially put her in danger.

${ }^{5}$ Due to visa and other restrictions my research took different shape than planned. I have never spent a full year in Daghestan, but instead between 2004 and 2018 I have spent there approximately 3 months each year in various seasons.
} 
that were made in everyday situations, at home, at work, in Islamic stores or mosques and during weddings, funerals and mawlids. ${ }^{6}$

During my fieldwork I was also under a lot of scrutiny. "You are not sitting decently", "adjust your veil", "you should wear a longer skirt for the mosque", "your ankles are not covered properly", "eat only with your right hand, it is the devil who eats with his left hand!". In certain situations (for security reasons or because my host did not want to waste time on explanations) I was introduced as my hosts' niece or cousin from Moscow, ${ }^{7}$ which put me under a lot of pressure to "behave accordingly". It is hard to estimate the impact of me "unintentionally going native" for my research, but it certainly raises some ethical concerns as to the usage of comments or stories that might have not been shared with me were I "a real foreigner". On the other hand, in certain situations I needed to re-emphasize my non-Russianness in order to be trusted by families with members "accused of Wahhabism" who live in constant fear of arrest or police provocation.

Religious organizations, institutions or clearly identifiable groups are a common starting point of many ethnographies in an urban setting. My interlocutors did not belong to any organization: they were wary of any form of religious activism. Their engagement in religious practices or strivings towards religious knowledge differed (and changed over time), but they all, at some point, called themselves "observant Muslims" or "simply Muslims". Over the decade I kept coming back to some of my interlocutors. With some I have lost touch, some left Daghestan or even Russian Federation and six, sadly, were killed. ${ }^{8}$ During my research I interviewed religious authorities, imams and Sufi sheiks but in this paper I purposefully focus on practices and narratives of the so-called "grass-root" Muslims. Most of the families I stayed with or visited were of rural-urban character: they (or their parents, in case of younger informants) migrated to the lowlands in the 1990s and still kept ties with their tukhum (lineage) and co-villagers, visiting them at least once a year. My interlocutors were both male and female, ${ }^{9}$ of different ages, different ethnic groups (with the predominance of Avars, the biggest ethnic group in Daghestan). They could be placed within middleand lower- income families. They derived their incomes from various activities: some held state-paid jobs, others took occasional jobs at construction sites or in small scale, usually unregistered businesses.

The gradual economic growth in Russia (starting in early 2000s) paired with the increase of numbers of the state-paid positions (which immediately increased the incomes from corruption $)^{10}$ influenced lives of my informants. Some of them got or rather bought ${ }^{11}$ state-paid positions, some, on the contrary, left them (for ideological

\footnotetext{
${ }^{6}$ The birthday of the Prophet falls in the third month of the Islamic calendar. In Dagestan the word mawlid also means a prayer said at a wedding, following the birth of a child, or at a cemetery. This term is sometimes used interchangeably with the word dhikr.

${ }^{7}$ My command of spoken Russian, lingua franca in Daghestan, was similar to the one of the native-speakers, which left my Daghestani informants puzzled.

${ }^{8}$ Among them Salafi-oriented journalists such as Akhmednabi Akhmednabiev and Hadzimurat Kamalov.

9 There was slightly more men whom I interviewed, however, everyday, informal comments I was more often acquiring from women.

${ }^{10}$ Information based on the presentation of Dagmara Maslova at the conference "Caucasus - between Europe and Asia" in Poznań, 4th-6th June 2018. The paper is forthcoming.

${ }^{11}$ A commonplace practice in Daghestan especially in regard to higher positions or positions of inspectors (who are not well paid but can make money on the side from taking bribes).
} 
reasons); some started to be involved in business. Most women were not employed, taking care of children and the household, some worked in schools and kindergartens.

\section{Daghestani studies and everyday Islam}

"Daghestan has been excluded from the mainstream of Islamic Studies, and Arabists (not to mention Persianists and Turkologists) tend to know little of the intellectual, legal, and literary traditions that were cultivated on this borderland of the former Russian empire for over a thousand years" writes Gould (2015: 21). Further in her foreword examining the state of art of Daghestani studies, Gould emphasizes the achievements of Moshe Gammer, Shamil Shikhaliev, Amri R. Shiksaidov, Michael Kemper, Vladimir Bobrovnikov and Natalia Tahirova. While there is a number of scholars (including Gould) working on the written culture of Daghestan, when it comes to the everyday life it has received very little academic attention, especially in regard to religious life. In-depth ethnographic descriptions of everyday life in Daghestan are scarce and contemporary religious life appears usually in the background of otherwise insightful ethnographies. ${ }^{12}$ Gould briefly approaches the everyday religiosity in her essay entitled "The modernity of premodern Islam in contemporary Daghestan" (2011). While her paper is very informative and insightful in regard to the history of Islam in the republic, the title is a bit misleading, since she only barely tackles the everyday life and draws conclusions on the present form of Islam out of, what seems like random ethnographic examples. ${ }^{13}$ Gould is aware of the scarcity of sources about contemporary Islam and rightfully notices that Daghestan, as a republic appears in academic and analytical literature mostly in reference to either linguistics ${ }^{14}$ or terrorism (Gould 2011: 177). Calls from the leaders of the Islamic underground are being analyzed, along with statements from Muslim clergy (Spiritual Board of Daghestani Muslims) or politicians. ${ }^{15}$ The terrorism or security studies or policy recommendations mostly rely on the second-hand data and as a result they are reproducing the discourses, in particular the division between "good" and "bad" Muslims that Mamdani has pointed to long ago (2002). We can, therefore, arrive at the conclusion, that with few exceptions Daghestan has not only been excluded from the mainstream of Islamic studies, but also, most likely for security reasons, from research-based anthropological accounts of contemporary religiosity.

In my analysis, I adopt a bottom-up view in the study of Islamic practice and draw on the analytical concept of "everyday Islam" (Schielke 2010; Marsden 2005) that calls for the study of religious practice as embedded in everyday, mundane life as well as family, economic, and social obligations. When I started my research I did not use the framework of everyday Islam explicitly. I was asking what it means for my informants to be a good Muslim, I was paying attention to local understandings of religious

\footnotetext{
${ }^{12}$ See for example: Karpov and Kapustina, 2011; Karpov 2010; Bobrovnikov 2011; Yarlykapov 2008.

${ }^{13}$ Later in the paper she explains that she "had come to Daghestan less with the intention to research contemporary Islam than with hopes of accessing archival material dating back to the medieval period" (2011), which justifies the use of ethnography as an additional material.

${ }^{14}$ There is a number on linguists working on Daghestani languages, for example: Diana Forker, Bernard Comrie, Zaira Khalilova, Rasul Mutalov.

${ }^{15}$ See for example: Gordon 2011; Moore 2015.
} 
discourses, practices and Islamic law. With time, I found this concept useful for framing my research, especially in discussions with orientalists or political scientists. At the same time, I was less convinced about evoking it when talking to anthropologists, who took for granted the exploration of religiosity as embedded in the mundane aspects of human life. Is, therefore, the concept of "everyday Islam" useful for the analysis of social life in the North Caucasus? What are its potentials and limitations and what should we be particularly cautious of?

Everyday Islam as an analytical concept has been broadly applied to the analysis of everyday life in Muslim societies or among Muslim minorities in the West. It emerged in opposition to studying Islam as a discursive tradition (initiated by Asad 1986), which was later called the "piety turn" (Osella and Soares 2009: 11). Numerous scholars (including Marsden 2005; Schielke 2009; Osella and Soares 2009) criticized the "piety turn" for putting too much attention to piety discourses and practices of self-discipline. Such an approach risked portraying Muslim subjectivities as shaped exclusively by scriptural discourses without taking into account the multiple normative registers and discourses that influence people's actions and shape their subjectivities. The "piety tradition" was considered highly normative, too much engaged with abstract concepts, whereas ordinary Muslims tried to integrate religion in different spheres of their lifeworlds. As everyday Islam framework was gaining popularity, it also received certain critique. Charles Hirschkind notices, for example, that "the notion of everyday life, as developed in the contemporary analysis of Middle-Eastern societies, has tended to reflect and valorize the normative standpoint of secular modernity." (2014) Nadia Fadil and Mayanthi Fernando also warn "against" the concept after noticing that there has been a tendency to position piety against the everyday, and that the secular-liberal background of some researchers have made them equate the everyday with the nonnormative (2015: 67). The concept of everyday Islam, in their view, became linked to "moderate" Islam, whereas Salafis fell out of it for being stricter, so somehow "out of the everyday". Following Deeb I would not see the above critique as working against the concept of everyday Islam, but rather as a warning to be more cautious of our grounding in epistemological commitments (2015). In response to Fadil and Fernando, Deeb (2015) has also suggested 'thinking together' the power of scriptural discourses to structure daily life and the creativity and potential of the everyday life that can complicate scriptural discourses. In the context of the North Caucasus it would be interesting to know if (and how far) the rather secular (and certainly influenced by the state's politics) discourses of the Muslim elite have a potential to start being interpreted as religious discourses (in Asadian sense) on how Muslims need to behave? That would also lead to the question how far state or rather its representatives are involved in shaping Islam in the region and in Russia as a whole.

The turn towards everyday Islam was paired with methodological shift. The shift from an analysis of the workings of a discourse on people's lives, or the analysis of the formation of a pious subject to the ethnography that focuses on the always-messy everyday life with religion as its component. The researcher has to rely on ethnographic material with all contexts and relationships our interlocutors navigate through in order to show how they influence the construction of subjectivity where religion is certainly not the only constitutive element (Abenatne and Cantini 2014: 13). For many researchers religious groups and organizations are the starting point for research on everyday Islam in a given setting, in particular in urban contexts (cf. Schielke 2018). 
While it may be somewhat methodologically "cleaner" and may work well for certain contexts isn't the "thinking through organizations" a Western bias? Shouldn't the focus on everyday Islam encourage a research beyond the clearly identifiable groups and religious organizations?

\section{Social, political and religious landscapes in Daghestan}

Daghestan is the biggest and the most multiethnic republic in the North Caucasus. Rural-urban migration, armed conflicts, rapid (re)islamization have influenced recent social changes in the region and everyday lives of its inhabitants. After the dissolution of the Soviet Union the inhabitants of mountainous regions of Daghestan were gradually moving from their mono-ethnic villages (which usually consisted of some to several tukhums) to the multi-ethnic lowland settlements or towns. An increased mobility has been accompanied by contestation of both localized village traditions (in some places inspired by Sufi brotherhoods) and secular lifestyles of the old-time city dwellers, with parallel strivings to make their lives more in line with Islamic teachings. The contestation of local ways of life was usually linked to the contestation of tukhums' control over its members. In most cases the village tukhums still exert power over the first generation of migrants and conversely, migrants have a say about village politics even if they no longer live there. Tukhum control is usually weaker when it comes to the second of third generation of migrants (Sokolov 2017).

The North Caucasus is the most unstable region in the Russian Federation. In the late $1990 \mathrm{~s}$ and early $2000 \mathrm{~s}$ the main factor contributing to the destabilization of the region was Chechen separatism: later, around 2009-2010, it was the activity of militants fighting to establish the Caucasus Emirate that considerably deteriorated the situation, in particular in Daghestan, Chechnya and Ingushetia (Falkowski and Marszewski 2010). The state's response to the militants' violence was also not without significance. Militants (or gangs posing as militants) racketeered businessmen who traded alcohol requiring "money for jihad", shops were burnt for selling alcohol or not paying the tribute to the militants, public houses (ambiguously called 'saunas') were attacked for "moral decay", and assaults on policemen were organized. Fortunetellers and healers were targeted for "sorcery". The armed state representatives (local police, Federal Security Service FSB, Federal army), on the other hand, conducted the "fight with terrorism" resorting largely to extrajudicial arrests and killings. The "zones of anti-terrorist operations" were established in various parts of the republic, and houses or flats were burned down and shot at. Tortures applied to extort "confessions" from alleged militants became a routine bureaucratic practice, part of the elaborate system of dependencies that links state representatives, corruption and blind violence (Raubisko 2011; Kaliszewska 2015).

The results of the prolonged destabilization paired with bottom-up (re)Islamization processes including: further migration of ethnic Russians and secular intellectuals (which started after the collapse of the USSR), establishment of enclaves governed by locally understood sharia (Kaliszewska 2016), and growing incomes from illegal 
trade and corruption. Slowly Daghestan, Chechnya and Ingushetia drifted away from the rest of the Russian Federation, much in the way Pakistan's tribal areas inhabited by Pashtuns (FATA) along the Afghan border, drifted from the mainland of Pakistan (Falkowski and Marszewski 2010).

In 2016 the so called Yaravaya law was introduced, targeting unregistered religious groups and preachers. I have not, however, found any evidence to confirm that this law has particularly influenced the unregistered religious groups in Daghestan (including the Salafi-oriented Muslims) - because they have already been targeted since the 2000s. This law was rather perceived as "just another law" that feeds the system, in which if a person is arrested (or kidnapped), "they will find the paragraph" to find him or her guilty. Curiously, my observations rather confirm the contrary: Salafi-oriented individuals receive less attention since 2014, that is after the involvement of the Russian Federation in Ukraine and the departure of Daghestani recruits to ISIS. ${ }^{16}$ There were also recently some political endeavors to re-integrate the region back into the Russian Federation paired with a noticeable shift in the way the North Caucasus and its inhabitants are portrayed in Russian state-owned media.

The religious landscape of the republic has changed dramatically over the last two decades. Rapid bottom up (re)islamization, involvement of the Spiritual Board of Daghestani Muslims in local politics and eventually ISIS recruitment have considerably influenced the Islamic practices and identities in the republic.

The Spiritual Board of Muslims of Dagestan (Dukhovnoye Upravleniye Musulman Dagestana; DUMD) also called the Muftiat, claims representation of Daghestani Muslims. ${ }^{17}$ Spiritual Boards of Muslims were state-created institutions functioning all throughout the Soviet times. After the dissolution of the USSR over fifty regional Spiritual Board of Muslims emerged, among them the DUMD. These institutions allowed (and to some extent still allow) the state a degree of ideological intervention and control. ${ }^{18}$ The DUMD, for example, supported the law that prohibits "Wahhabism" on the territory of Daghestan, although no such law exists on a federal level. ${ }^{19}$ It was also supposed to be in control of all transnational Islamic organizations active in the region and enforce censorship on Islamic literature introduced in the early 2000s. However, conversations with informants working for the DUMD and affiliated institutions showed that the power and will of the DUMD to enforce this law could be rather limited. It can be seen as "just another law" that may be evoked when needed, but which is not really respected.

On the everyday basis the DUMD promoted Muslim's spirituality and ethics, observance within the "legitimate religiosity". The "traditional", "moderate", "official" or "local" was positioned against "non-traditional", "radical", "unofficial" and "foreign". ${ }^{20}$ The DUMD and other Muftiates across Russia were famed for ideological

\footnotetext{
${ }^{16}$ The number of cases of persecutions and extrajudicial killings has also dropped (some arrests or tortures are not reported). This however does not mean that persecutions are rare, some arrests and tortures are also not reported.

${ }^{17}$ For more details see for example: Omelchenko and Sabirova 2003; Ware and Kisriev 2009; Knysh 2007.

${ }^{18}$ However, bearing in mind the support and more recently the financial capital of DUMD its political power and potential autonomy from local secular authorities should not be underestimated.

${ }^{19}$ In 1999 "Wahhabism" has been outlawed in Daghestan, in 2010 in Chechnya and Kabardino-Balkaria. For more see: Malashenko 2014.

${ }^{20}$ See for example: Pilkington and Yemelianova 2003; Omelchenko and Sabirova 2003.
} 
fighting the "Wahhabis" and producing discourse portraying the latter as a threat to other Muslims and the state's security. This was particularly true until recently. The DUMD authoritative figures gave "instructions" how not to get involved with Wahhabis, suggesting, as a solution, following the teaching of the sheikhs. ${ }^{21}$

The DUMD with support from the government of the republic, advanced a religious ideology that differentiated between "bad" and "good" forms of Islam: "non-traditional Wahhabism" and "Sufism/traditional Islam". ${ }^{22}$ Both of these labels were used in the media and in everyday speech to refer to two specific set of "attributes". The first one included: beards, lack of underwear, rolled-up pant legs, eschewal of local traditions of pilgrimage, festive weddings and funerals, specific way of praying, reading literature classified by the DUMD as "extremist." The second one (traditional Islam) included: practice of visiting ustazes and making the ziyarat, ${ }^{23}$ the celebration of Novruz Bayram (Spring Holiday), New Year, and the practice of mawlid. The DUMD maintained that the "Wahhabis" received funding for their operations from Western organizations that sought to break up Russia, as well as from organizations in Arabic countries funding terrorism abroad. In the meantime, due to state and DUMD politics Daghestanis found it more difficult to travel abroad to study (Ware and Kisriev 2009).

The "anti-Wahhabi" discourse became very much grounded in the political discourse of the region. I will not describe the discourse in details, ${ }^{24}$ however when referring to the above discourses I use the terms "Sufism" and "Wahhabism" in quotation marks for the reasons outlined below. The word "Sufism" thus did not necessarily refer to the tradition of Islamic mysticism. ${ }^{25}$ The same was true of the term "traditional Islam," which wasn't necessarily used only in reference to individualized religious practices steeped in local traditions. Both terms "Sufism" and "traditional Islam" encompassed the entirety of practices that were deemed acceptable by the DUMD and republic authorities and were not otherwise classified as "Wahhabism." Also, the terms "Wahhabism" and "Wahhabis" were used not in reference to the Islamic reformist movement guided by the belief that the Quran and the Sunnah are the sole basis for the faith, a movement inspired by the tradition passed down from the Hanbali theologian Muhammad ibn Abd al-Wahhab. Instead, they were used as a sort of epithet used by politicians and official media outlets in the former USSR to brand religious, political, and social organizations as well as individuals. Some similarities may be made to the way anti-religious propaganda worked during the Soviet Union (Marszewski 2007), when undesirable printed matter was eliminated and "correct ideological spin" was put on every item and in every official speech. The politics and activities of DUMD were changing over time. Slowly, they started to engage with Muslims-as-believers rather than Muslims-as-political-subjects (cf. Benussi 2018 in this issue). This change was, most likely, not the reason, but the result of the shift in

\footnotetext{
${ }^{21}$ In the North Caucasus context "traditional Islam" is understood primarily as Sufism while in the Volga-Ural region more emphasis is put on the Hanafi maddhab in the understanding of traditional Islam (see Di Puppo 2018; Di Puppo and Schmoller 2019).

${ }^{22}$ For similar practices in the neighboring Chechnya cf. Raubisko 2009.

${ }^{23}$ Ziyara from the Arabic "to visit": a pilgrimage or place of pilgrimage. In Daghestan names that ended with a vowel often aquired "t" at the end. Maria became Mariat, Aisha became Aishat etc.

${ }^{24}$ For a detailed account see Knysh 2007.

${ }^{25}$ In depth accounts of Sufism in Daghestan can be found in Gammer (ed.) Gammer 2009.
} 
perceptions of Salafi-oriented Muslims, that I will analyze in this paper. This shift could no longer be ignored by DUMD and had to be accommodated.

\section{Changing narratives about Salafi-oriented Muslims}

In this paragraph, I look at the everyday narratives, comments and opinions about Salafi-oriented Muslims that were shared with me over the course of 2007-2017. I argue that the local understanding of the term "Wahhabi" changed considerably between 2007 and 2017 - it drifted from being strongly influenced by "anti-Wahhabi" discourses to being shaped by one's own and other's experiences. I could retrace these changes analysing my fieldnotes and interviews. My analysis is thus based on shifts that I could identify in different periods of my field research as shown in the fieldnotes I gathered between 2007 and 2017. I noted this shift in the way the topics of my conversations changed. I will discuss the possible reasons behind the change.

Analyzing the fieldnotes collected between 2007 and 2009 I noticed that during that part of my fieldwork, I heard numerous stories of neighbors and distant relatives who had been "brainwashed" by "Wahhabis." People shared advice on how to spot a "Wahhabi": "the look in his eyes," "a beard and shaved mustache," "rolled-up pant legs," "no underwear," and, in the case of women, "a black hijab or nikab" were all alleged signs. If somebody totally quit drinking or smoking he also immediately was suspected of "Wahhabism". The everyday life habits or outfits that might have been seen before as not particularly important, rose to the attributes that young people were scrutinized for by their parents and relatives. I repeatedly heard different versions of the same narratives, questions and concerns. "Is it curable?", "Is it a spell you can break?", worried one acquaintance whose son had simply begun praying and attending the mosque. "How can I tell if my sons did not fall into the clutches of Wahhabism?" (female, 35 years old). Weddings and funerals were the social spaces that gather together tukhum (lineage) members, co-villagers, neighbors and work and classmates. Women and men are seated separately, questions are asked over the tables filled with food, questions that very often spark emotional discussions about the wedding itself, about family members and their often complicated life trajectories. Between 2007 and 2012 a wedding with music and dances, abundance of food and alcohol was considered (by most of interlocutors, especially the middle-aged and older) "proper" in contrast to a silent wedding with nasheeds and no alcohol. It "signified" that the newlywed and their family is not "affected by Wahhabism" and was perceived as a "relief" by relatives. Over food whispered comments were shared about the absence of certain family members, who refused to participate in a wedding (refusals to participate in funerals were less frequent), families who "allowed" their loved ones to become "a Wahhabi" were judged or pitied. "Why did they allow this? Such a respected family. They must have not controlled him enough/they missed the moment". "What did they do wrong? Maybe he will get over it soon". "Such a grief (takoe gorye) for the whole family!". Some families cut ties with their loved ones for "joining the Wahhabis" and "turning their backs against the family". There was a general perception of "Wahhabis", as something "evil" and foreign to Daghestani culture. Such statements were usually expressed during general comments about the unstable situation in the republic for which "Wahhabis" were blamed. "Every last Wahhabi needs to be killed in 
order to keep the peace!" said a man in his 60 s. There were references to Stalin, who "would have known what to do with them long ago" (male, 55 years old). He felt threatened not only by the Wahhabis but by a general rise in piety, that was often seen as a "suspitious" sign that a person is on the way to become a Wahhabi. The narratives and emotional statements like the ones above were not rare, very often they were expressed in response to general complaints about the post-Soviet reality and the living standards in the North Caucasus. Sometimes they were a direct result of the DUMD's teachings where "Wahhabism" was portrayed as alien to Islam. The DUMD potential to present their teachings (including their stance on Salafi-oriented Muslims) as compliant with the normative discourses is also important to take into account.

"It's best to stay away from Wahhabis. Don't make friends with them-they're dangerous," said Magomed. He was 22 years old and lived with his parents unable to find a job. He hung out with a group of peers his age or younger. It is from them that he "acquired" Islam. His parents were of a middle-class first generation rural-urban migrants, not religious, a bit nostalgic towards the USSR and relatively successful in the market economy. They were concerned about Magomed becoming observant and being unemployed. They feared he would be attracted by the Wahhabis, so they provided him with videos and books on the "Wahhabi threat" issued or supported by the DUMD.

“They're not Muslims - they're thugs!, he continued. They give Islam a bad name. They ought to get rid of every last one of them! I'm sure they're getting paid in dollars. Why else would anyone join them?"

"Who's paying them?" I asked.

"Forces that are bent on destroying Russia. Organizations from England. I saw a show about it on TV. They're getting paid. Why would anyone join them? They're brainwashed. I can give you a copy of the DVD "The True Face of Wahhabism" and you'll see what Wahhabism is all about. It explains everything. Do you have a USB drive?" Magomed has put various anti-Wahhabi films on my pen-drive, films that were widely accessible in some of the Islamic shops and on the internet sites.

It turned out only later that Magomed and his friends, with their (in my perception) black-and-white stance on "Wahhabism" knew young men considered "Wahhabis" from their city. "Look, the Wahhabis live over there!" - commented the oldest in the group pointing to a blue gate on the main street in Kyzyljurt, while we were driving towards a mosque. "Are you scared?" - joked Magomed. "No worries, these are our Wahhabis, they are peaceful Wahhabis" - continued the oldest.

On our way back to Magomed's apartment his friend pointed to the half-burned house. "They (armed forces, police) were bombing/targeting it for 12 hours last month and killed one person. It's understandable. They are paid per hour." The 
young men did not know the people who lived in the house (they knew, however the people who were their relatives and were "accused of Wahhabism".)

The speeches, sermons and publications of DUMD, perpetuated by state officials have been successful, at least between 2005 and 2009, in creating and maintaining the "moral panic" around "Wahhabism". There was, however, a distinction between those "Wahhabis" one has never seen, the foreign ones portrayed by the media and "our Wahhabis", who somehow did not fit the picture. It is, however, important to note that the support for the annihilation of "Wahhabis" did not necessitate support for the military actions carried out by local and federal authorities, especially in one's neighborhood. Army and police operations were often perceived as "money laundering" and "a racket" set up to extract bribes from the local community, whose members were appalled by these campaigns. They believed that the siloviki ${ }^{26}$ would often knock down the wrong doors. When the number of "special operations" grew, so grew the doubts about the people they were targeting, especially if they were one's relatives or neighbors.

The shift from unreflective use of the terms "Wahhabism" or "Wahhabis" towards a more nuanced one was observable around 2009-2010. I will consider possible reasons behind the change later in this paper. While some of my friends continued to share stories about youngsters who had been "brainwashed" by the "Wahhabis," more and more people were beginning to doubt the veracity of these tales. "Has anyone even seen these Wahhabis?" (male, approx. 30 years old). "Are they even real?". "This all sounds strangely convenient for someone." "They made up the Wahhabis so they'd have someone to blame for their problems." "They (the authorities) are the real Wahhabis" (female, approx. 30 years old).

Around 2009-2010, instead of stories about "wicked devils," I would hear reports about an atheist who had been "turned into a Wahhabi" by the siloviki, and who reportedly had killed him after he came out of his house brandishing a weapon, yelling "Allah akbar!", and how "Wahhabism" was being used as a cudgel against political opponents (male, approx. 60 years old). The same subjects who had grumbled about "Wahhabis" just one year earlier were now growing increasingly skeptical of their supposed responsibility for the rampant corruption and violence. Gradually, the individual experiences of my informants and the accounts they heard from their relatives or neighbors started to be quoted more frequently, shaping the views on social and religious life. "There's nothing wrong with Wahhabism itself. Wahhabis are Muslims just like us. Wahhabism is the official religion of Saudi Arabia and look how well they're doing!" (female, 50 years old).

The ideas about the excessive spending for weddings gradually gained a growing number of followers, both among the poorer part of the society as well as among the urban-rural youth who saw the tradition as a "village-like" burden. While most weddings were still organized in an old and festive ways, more and more often quiet weddings were praised for being peaceful, with little risk of drunk relatives getting into a fight, with no excessive spending of money that could be used for other purposes, like starting one's own business.

\footnotetext{
$\overline{26}$ Term commonly used to denote state officials who are carrying weapons in particular police, army and other special units who target the alleged 'terrorists'.
} 
By 2010 and 2011 questions about "Wahhabis" would elicit different responses: "One of my friends is a ... well, you know ... what to call them ... a Wahhabi, and he's a decent guy" (male, 34 years old); "They call them Wahhabis. Let me tell you: if everyone was like those Wahhabis and lived their lives that way, then the world would be a better place" (female, approx. 50 years old). Young pious people were now more likely to be described as those who "plunged into religion" (ushili v religiyu) than as "vicious Wahhabis" who need to be dealt with. There was a certain reluctance in the way my interlocutors pronounced the term "Wahhabi" knowing well how politically loaded it was. Some avoided it or resorted to more descriptive narratives: "My daughter's husband, he's a ... he doesn't go to weddings, he doesn't drink — any girl would be lucky to have a husband like him!" (female, 50 years old).

To replace the politically loaded term "Wahhabis" certain new terms appeared such as Salafi or peaceful Salafi (mirnye Salafity) and were applied to those Muslims who were rejecting or were not familiar with the Sufi practices and the local traditions associated with them. However, even Salafi-oriented groups rarely used this label to identify themselves. My Salafi informants would rather use emic terms such as: techeniye (the flow), jedinobozhniki (one's God's people) or praviednye musulmaniye (the rightful Muslims) or would not use labels at all. The majority of my informants would say "we're just Muslims" or "we're just observant Muslims". They would say so both about themselves and their neighbors or relatives whom they have described as "Wahhabis" a couple of years earlier. They no longer lived the divisions, although they were perfectly aware of the political power of the official categories, and had a good knowledge of the "attributes" ascribed to the Salafi-oriented Muslims and adherents of Sufi brotherhoods.

Below I provide a short except from my field-notes (2008, 2010 and 2011) to illustrate the gradual detachment of the official categories from the everyday life.

Husain, a male in his late 30 s worked in the library in Makhachkala but since the income was insignificant he also grew greenhouse tomatoes for sale. I first met Husain in the spring of 2008 . He appeared to be rather wary of my colleague 27 and me during our first conversation. He talked about his home region, and about tradition and Islam. He mentioned that he had a shaykh in his family (leading me to conclude that he was not a "Wahhabi"), but avoided exploring this topic further. In a village he brought us to an imam who strongly disliked "Wahhabis" (whom he equated with militants) but honestly admitted to never having met one. When we met again two years later, in 2010, he spoke with much greater candor about himself and his dilemmas:

"Who am I, really? One of my ancestors was a shaykh, a respected, upstanding person. Yet I don't make the ziyarat, I don't visit shaykh, and I'm not a murid. But I do take part in the $d h i k r$ at a funeral, as you saw. How could I not pay my respects to the dead? I couldn't do that to his family," he added, referring to the funeral for a policeman killed in a special operation which we had attended the previous day.

\footnotetext{
${ }^{27}$ At this stage of my research (Spring 2008) I was accompanied by Maciej Falkowski of the Centre for Eastern Studies in Warsaw.
} 
"But if you look at my beliefs, then I'd say I'm closer to ... you know ... Wahhabis. They're right: there's no need for intermediaries or all the superfluous rituals that grew out of tradition. Islam in its pure form is fine for me."

"There are many others like me," Husain continued. He realized that people who did not subordinate their practices to the DUMD were treated unjustly. He condemned the security services for treating innocent, devout Muslims as militants. When I asked about the second person killed in a shooting, who took life of the policeman, I expected him to blame it all on the militants or "Wahhabis". He, however, calmly said "He was from a neighboring region, a man in his twenties, not even married yet [..] He was Muslim just like everybody else [... . They [militants] have no choice. There's a limit to how much abuse and humiliation they can stand," he said a bit later.

"They call us all Wahhabis. If you roll up your pant legs, you're a Wahhabi. If you wear a beard, you're a Wahhabi [..]. I wish I could grow a beard like the prophet Muhammad, but people wouldn't understand, especially in my family's village. Our imam is very strict about such things: no exceptions."

Husain had a great respect for the imam, he admired the religious work he has done in the village, where in the early 90 s only the eldest were observant, while the middle generation was abusing alcohol for most of the day. Imam introduced (locally understood) elements of Sharia, the use or trade of alcohol and cigarettes was forbidden under a fee paid to the mosque, festive celebrations were banned, the mosque was filling up everyday.

"What good are all these divisions in Islam? We're all Muslims," he said.

Husain did not feel the need to declare himself and position himself against the official categories. He did not inhabit them. The official categories came from a different register and were evoked when confronted with a researcher or a non-religious colleague, but in the everyday life they were not a point of reference for him. He was however perfectly aware of their existence and the risks behind being identified as a "Wahhabi". Gradually, both for Husain and most of my informants, a vicious "Wahhabi" became just an empty word from secular registers, a word without a content, a word that was not to be used towards real people. What mattered most to Husain was being a good Muslim, a good husband and father. Regular prayer, obedience to the rules of Islam, and setting an example for others so that they, too, would turn to Islam, were his everyday concerns. He was concerned with living a rightful life which was not easy in a republic permeated by corruption and violence. He did not want to take or give bribes, but sometimes everyday situations forced him to act against his will. "It is hard to be a good Muslim in this corrupt country", he would complain. Eventually, in 2011, he would consider leaving his state-paid job for business, where, as he said, there was more income and less of the "dirty things", by which he meant the bribing, taking kickbacks and other commonplace practices in the Russian Federation ${ }^{28}$ and Daghestan in particular.

${ }^{28}$ For more see Ledeneva 2013. 


\section{The reasons behind the change}

Below, I will briefly outline two possible reasons behind the change of attitudes towards Salafi-oriented Muslims: (1) the changing character of the bottom-up Islamization and (2) the growing distrust towards authorities.

The most important process that influenced the change was the evolving character of a rapid bottom-up Islamization in the republic. In a matter of several years, for most of my interlocutors "being Muslim" went from an identity marker to a way of life, which encompassed various everyday spheres. Daghestani Muslims gradually embraced Islam as a way of living, seeing themselves and others first of all as fellow believers. The official categories, though acknowledged and understood started belonging to a different register.

In Daghestan in the late 1990s and the early 2000s a growing number of mosques were being built and more people than before openly identified as Muslims. Initially, however, for the majority of my interlocutors identifying as Muslim was not followed by religious practice or any considerable changes in the everyday routines. The declaration "I'm Muslim" was very often similar to saying "I'm Avar" ${ }^{29}$ " or "I'm from Daghestan". Religious identity was going hand in hand with the ethnic one. ${ }^{30}$ National revivals in the 1990s (for the most part) were parallel to the religious one. Vivid and turbulent in the 1990s (Gammer 2002) national revivals started to fade away near the turn of the century. ${ }^{31}$ The opposite can be said about the religious revival. Gradually, however, it started to assume a different form. "Being Muslim" went from being a "feature of the national identity" to "a way of life" (Kaliszewska 2016), encompassing different everyday life areas, such as work and nutritional choices. I observed how it evolved between 2007 and 2017. Different questions were being asked, different concerns raised. With each passing year of my research, it was the everyday life, everyday habits, obligations, nutritional and fashion choices that were constantly changing. With every subsequent year or season more women could be seen wearing hijabs, and growing numbers of people attended daily prayers at mosques. In the month of Ramadan, restaurants and cafés would close during the day, less and less men could be seen smoking in the streets. Supermarkets did not trade alcohol, at least not officially. More and more marshrutka (mini-bus) drivers were playing nasheeds ${ }^{32}$ and Islamic sermons in their vehicles instead of the traditional Russian or Daghestani pop songs. It was difficult to order a taxi during afternoon prayers on Friday. "Sorry, there are no drivers available right now. Everyone's at ruzman (the main Friday prayer service)," one cab dispatcher told me. Questions such as "Are you a believer?" and "Do you pray?" became "ritual" questions posed to newly met people. Before the list of "standard" questions included inquiries about a person's national identity, but nobody was asking about individual religious practices. Among my interlocutors it

\footnotetext{
${ }^{29}$ The biggest ethnic group in Daghestan.

${ }^{30}$ My informants claimed that before the dissolution of the Soviet Union they and their parents have only made a distinction between local Muslims and Russians (the latter included also people from Belarus, Ukraine, Moldova or even Poland). For more examples from other regions see for example: Brubaker 2004.

${ }^{31}$ For various reasons, including the centralization politics of Putin but also the simple wearing out of ideas that has never been really grasped by the majority of this multiethnic society. More on ethnic issues in Daghestan: Kaliszewska 2016; Ware and Kisriev 2000.

${ }^{32}$ Islamic songs with lyrics that focus on religious themes.
} 
was not rare to come across discussions or remarks on what is proper in Islam and what is not, who prays properly and who does not. "How to make up for the missed prayers?", "How do I know which direction to pray to?" "How do I pray on train?" "Can Muslims give bribes?". Some of my interlocutors would initially just stop by an Islamic store to purchase cosmetics, Islamic tooth-paste or black cumin oil. Some would come to get "amulets" for drivers, Mecca calendars, prayer beads, and rear-view mirror surah pendants. With time they would come and chat with the salesmen and gradually reach out for popular reading material covering the "technical" aspect of prayer, the positioning of the body during namaz (the daily prayer), and the duties of Muslim men and women. Islamic stores in Makhachkala carried increasingly large stocks of religious book and guides, translated from Arabic, with titles such as: "How to Pray Namaz," "How to be a Good Wife," and "Islamic Medicine." Most conversations focused on practical aspects - theology driven questions were rarely debated among local Muslims. ${ }^{33}$ Big family gatherings, especially weddings and funerals were good occasions for such debates. "What is a proper wedding for Muslims?" "Can we have dances?" An increasing number of weddings I attended were not preceded by a registration required to be officially recognized as husband and wife by the law of the Russian Federation. An Islamic ceremony in mosque was found sufficient. ${ }^{34}$ In case of funerals changes were not so immediate, but gradually the new questions and concerns appeared: "Is reading Quran at the cemetery wrong?", "How about dhikr?", "Is putting a picture on the tombstone (very popular in the Soviet times) acceptable?" The number and the kind of questions that were being asked among relatives, co-villagers and the long rumination that they sparked points to the increased importance of practical knowledge, which, for the most part, has not been passed on from parents or grandparents.

Bobrovnikov (2011) points out that overt manifestations of Islamization in Dagestan were not accompanied by commensurate increases in religious knowledge. In his view, low academic standards at universities, madrasas, and maktabs, paired with the superficial knowledge of Islam prevalent among contemporary Muslim scholars, are evidence against a supposed "spiritual revival of Islam." Bobrovnikov provides convincing data and examples, my field material also confirms that, at least initially, the religious knowledge of my interlocutors was superficial. That however, does not imply that the intensive changes in everyday religiosity did not take place. While, with few exceptions, my interlocutors knew little about the scriptural knowledge and for the most part did not know Arabic or read Quran, they certainly acquired practical, embodied knowledge of prayer and proper conduct. While Bobrovnikov sees religious knowledge through the prism of scriptural knowledge, I argue that we need to take into account everyday religious practices. Exploring the everyday Islam allows us to see changes that could go unnoticed, if the religiosity was measured on the level of scriptural knowledge among population. Although the scriptural knowledge did not grow significantly among my informants ${ }^{35}$ everyday observance and religiosity became

\footnotetext{
$\overline{33}$ Imams, or alims in DUMD were certainly debating on scriptural knowledge in Islam, there were also some individuals who studied in the Middle East and who had more profound knowledge - my analysis, however, is based mostly on grassroot Muslims, who focused first of all on practical aspects of prayer.

${ }^{34}$ It was also more practical in regard to changing documents and in case the couple divorces.

${ }^{35}$ The scriptural knowledge certainly grew among young urban Muslims and religious leaders but I purposefully do not focus on them in this paper.
} 
their way of life, and started mattering more than discourses that came up from different registers, perpetuated by secular actors, mostly from older and middle aged generation.

The generational change was also not without significance. For young people the official categories came from the world of their parents and grandparents, some of whom longed for stability of the Soviet Union, grumbled about "growing out of Islam", learning English and going to Moscow. They came from "their world", from talks and disputes that young people felt disconnected from, from TV they exchanged for internet and Youtube videos. They came from the sphere they alienated themselves from and exchanged for socialization with young fellow-Muslims. Seeing themselves as religious and observant, enabled my informants to see others, even if initially scapegoated (like Salafi-oriented Muslims) individuals and groups as first of all as religious subjects and fellow Muslims.

The second important reason behind the gradual change in understanding of the Salafi Islam was violence (with peak around 2009-2010) of the power structures (police, armed forces, FSB). More and more people fell victim to extrajudicial arrests, tortures and persecutions for real or alleged ties to "Wahhabis". Among them were relatives, neighbors, classmates. Around 2009-2010 the more frequent clashes between the militants and police/army started to be perceived as unjust towards the former. This is not to say that actions of militants were cherished or that there was a significant resistance towards the state among the majority of population. There were, however, numerous comments and narratives that pointed out that the violence generated by the militants (who usually targeted policemen or army, but not civilians) is insignificant compared to the violence produced by the state. Very often there was also more compassion on the side of the militants ("they could bear the humiliation no longer"), while the state's violence was perceived as impersonal, "systemic" and done for the purpose of one's career. Also, the more and more frequent accusation of "Wahhabism" of the political opponents deprived this label of religious content. The distrust and anger towards the authorities (despite general support for Putin, and Edinaya Rossiya and no real claims on independence $)^{36}$ were significant factors that enabled most of my interlocutors to see Salafi Islam in a different light. The distrust towards authorities increased after the murder of Sufi sheik Said Effendi in 2011 in his house in Novyi Chirkey. The "Wahhabis" were blamed for the murder by the secular and religious authorities but (despite the initial outrage) nobody I talked to seemed to believe in this accusation. The main narrative, from both religious and non-religious people, those Salafioriented and the murids of Said Effendi was: "the FSB (Federal Security Bureau) was behind the murder". True or not, this narrative was a powerful one. Before his death Said Effendi was working towards reconciliation with the Salafi-oriented Muslims. He considered inter-confessional divisions and conflicts working against the Muslims in Daghestan and wanted all Muslims to live in peace even if they did not agree on certain issues. His initiatives, along with the gradual changes in the everyday religiosity might have also contributed to the perception of Salafi-oriented individuals first of all as fellow, observant Muslims.

\footnotetext{
$\overline{36}$ This topic is analyzed in detail in Kaliszewska 2016.
} 


\section{The results of the change}

The grass-root changes in perception of Salafi Islam were followed by changes in the DUMD discourse. It is important to emphasize here the role of grass-root opinions and perceptions that could no longer be ignored if the DUMD was not to lose its influence which has never been too strong in some regions of the republic (especially the South).

Gradually, inter-confessional divisions strongly emphasized by the DUMD until 2011 started to give way to "anti-radicalism" and "anti-extremist" narratives. The Muftiat started to focus more on Muslim's spirituality and ethics as well as on social projects and charity. However, they still had (and have) to take into account state's discourse on "safe" and "unsafe" Islam and propagate the former. The DUMD discourses became, however, more nuanced. Terms such as "Wahhabis" or "Wahhabism" stopped appearing in the DUMD publications around 2014. Speeches and texts on rightful observance, Islamic holidays and Islamic economy took over preachings about "Wahhabis" threatening state's security. There were no longer "Wahhabis" that were targeted as potential terrorists but the more vague "radicals". The "sets of attributes" that were well grounded in the DUMD and state-media discourse were slowly modified. The beard stopped being an "attribute" of a "Wahhabi" and many individuals grew beards (though not without a certain caution) to resemble Prophet Muhammad. There were recommendations towards having peaceful, alcohol-free weddings and funerals. Hijab, initially considered "Wahhabi" became a proper dress code (supported also by the DUMD officials), with an unwritten recommendation not to use black or dark ones. The Salafi-oriented Muslims continued joking that "you see, it just takes them [DUMD] time to realize that we are right after all". "There will be a day, when they finally understand who is the rightful Muslim". "They are always a couple of steps behind us" (Abubakr, in his 30s).

\section{Reproduction of form}

Religious and state authorities seem to have failed and at the same time, succeeded at producing a "good" Muslim. ${ }^{37}$ They failed at shaping individuals who discredit Salafioriented Muslims in the everyday life. They did not manage to shape obedient political subjects, but partly succeeded in creating the religious ones. In places where certain religious orientations are "outlawed", where violence and arrests are an everyday occurrence, individuals or groups need to juggle or play with multiple expectations, opinions or ideologies. Every lifestyle choice is like making a statement, often unintentionally. Some of my informants (including Husain) attempted to place themselves "on the safe side" when speaking to me for the first time, emphasizing their distinctness from the "Wahhabis". The boundary between the practiced and the believed, between the concealed and the revealed (particularly to outsiders) was blurred and shifted depending on the context, the interlocutor, and his or her trustworthiness.

\footnotetext{
${ }^{37}$ I engage here with Alexey Yurchak's analysis of the life and discourses in the late socialism "Ultimately, the announced Party project for the creation of the New Soviet Person was both successful and un-successful." (2006)
} 
Zarina, aged 34, was a saleswoman in an Islamic store in the vicinity of the Djuma Mosque in Makhachkala. She has recently devoted herself to Islamic observance, put on a hijab and a long dress. Her store offered clothing for women imported for the most part from Turkey. "Some people, especially the police, have trouble understanding that we don't sell anything illicit here. They see a girl like me wearing a hijab and they call me a 'Wahhabi,' or a terrorist. That's why we lay these books out - just to be on the safe side," she said, gesturing at a pamphlet book titled "Beware: Extremism!" displayed on her desk. I asked if she has read the book but she just smiled as if surprised by my question: "No, why, of course I haven't" [..]. "But it is of course not that I support extremism" - she added a while later.

Despite initial success of accusatory books, videos or speeches performed both by DUMD officials and state authorities the anti-Wahhabi rhetorics seemed to have taken roots only superficially: Wahhabis were decried in certain contexts, accusatory speeches were made in the presence of larger (or untrusted) groups, "appropriate" printed matter was displayed conspicuously. By the above example I do not intend to emphasize the opportunistic or "underground" character of these practices. Rather, certain analogies can be drawn here to the mindless repetition of Soviet rituals such as May Day parades, speeches, and assemblies, which existed as a "form" that was increasingly removed from social practices and actions (Yurchak 2006). Alexey Yurchak in his paper defines a heteronymous shift as an "act of the reproduction of form with the reinterpretation of meaning", emphasizing that it "cannot be reduced to resistance, opportunism, or dissimulation" (2006). In line with the DUMD's teachings and state's expectations, the Daghestani Muslims reproduced the DUMD's discourses on the level of form: they manifested support, did not argue with the necessity to solve the "Wahhabi problem" nor with the framing of the "Wahhabi question" as a problem. But, contrary to DUMD's expectations, many Daghestani de-ideologized DUMD's teachings by merely reproducing the ideological layer (with little meaning attached to it) and focusing on the practical one, following the DUMD advices that were meaningful to them, that is, for the most part these concerning everyday life. They reinterpreted the meanings of "being a good Muslim", rendering it meaningful on their own terms.

\section{Conclusions}

In Daghestani context we seem to observe a situation in which a religious vocabulary and theological references are used in a secular sense. The theology driven qualifiers such as "Wahhabis", "traditional Islam", "Sufism" are used with no clear religious content attached to them. When Daghestani Muslims start to practice religion, even if their religious knowledge is limited, they often do not see the above categories as related to their everyday experiences. At the same time, these categories are not completely separated from their daily lives, because they need to refer to them in certain circumstances to "stay on the safe side". Also, the media and the official public space is so saturated with the "secular-Islamic" discourse that it is difficult to completely stay away from it. Through this discourse the Muslim official elite aims to exert some control from above on religious practices but this control is 
limited: the laws are often not enforced (but can be used when needed - the link with Soviet practices can be traced here ${ }^{38}$ ) and, just like in the late Socialism, people are skillful at reproducing the form and re-interpreting the content.

The literature on everyday Islam is generally more concerned with the dynamics between everyday religious practices and scriptural teachings/knowledge. In case of the North Caucasus, I would suggest exploring, in a similar fashion, the dynamics between everyday religious practices and the "secular-Islamic" discourses of Muslim elites.

Concluding, I would also suggest re-considering the "thinking-throughorganization" in regard to exploration of everyday religiosity in the post-Soviet context, where belonging to a movement or an institution other that one's workplace is rare and sometimes viewed with suspicion (again, a Soviet legacy). The question remains if it is the everyday Islam framework that shall be re-adjusted to provide us with better tools to explore the "gray zones" of the religious everyday or rather it is the post-socialist framing that could be added to the analyses of the religious live of grass-root Muslims in the post-Soviet contexts?

Researching only the clearly identifiable groups in the North Caucasus would limit our exploration to Muslims supporting Spiritual Boards of Muslims or a number of small Sufi brotherhoods. It would leave out of the picture the most active part of the population, those who call themselves "simply" or "observant Muslims". They are not an organized entity, rather a set of loosely connected networks, and yet, they are the ones that are most actively engaged in strivings to make individual lives and the society more in line with what they see as Islamic teachings. Observant Muslims in Daghestan, are neither a marginal or an elitist group (like members of halal movement in Kazan as described by Benussi in this issue). Leaving them out would mean overlooking the actors and processes behind the recent social changes (cf. Jourde 2009). Daghestani "observant Muslims" do not have any legitimate space in the public sphere and they are unlikely to have one, bearing in mind the neo-authoritarian regime of the Russian Federation and the post-Soviet attitudes towards the state, law and religious activism. Issues of everyday religiosity and citizenship are not easily separated and we shall bear that in mind when researching the everyday Islam in the post-Soviet setting.

Acknowledgements This paper is based on the field material from various projects. Between 2007 and 2011 my research has been financed by: University of Warsaw, National Science Centre (2009-2011, no. N/N109317037), and myself, between 2012 and 2018 by the Volkswagen Foundation (project based at the University of Bamberg entitled: Documenting Dargi Languages in Daghestan: Shiri and Sanzhi) and between 2016 and 2018 by Narodowe Centrum Nauki (National Science Centre), research grant number 2015/19/D/HS3/02362. Special thanks for suggestions and proofreading to: Asmaa Donahue, Lili Di Puppo, Jesko Schmoller, Renata Hryciuk, Anna Horolets, Karolina Bielenin-Lenczowska, Sebastian Kaliszewski, Helena Patzer.

Open Access This article is distributed under the terms of the Creative Commons Attribution 4.0 International License (http://creativecommons.org/licenses/by/4.0/), which permits unrestricted use, distribution, and

\footnotetext{
$\overline{38}$ More on the practices and perceptions of law in the Caucasus in Kaliszewska and Voell 2015 and on affective dimentions of legal practice within counter-terrorist zones: Kvedaravicius 2018.
} 
reproduction in any medium, provided you give appropriate credit to the original author(s) and the source, provide a link to the Creative Commons license, and indicate if changes were made.

\section{References}

Abenatne, P., \& Cantini, D. (2014). Introduction. Life-worlds and religious commitment: Ethnographic perspectives on subjectivity and Islam. La Ricerca Folklorica, (69), 3-19. Retrieved from http://www. jstor.org/stable/43897023. Accessed Nov 2018.

Asad, T. (1986). The Idea of an Anthropology of Islam, Washington, DC: Georgetown University Center for Contemporary Arab Studies (Occasional Paper Series).

Benussi, M. (2018). "Sovereign" Islam and Tatar "Aqīdah": Normative religious narratives and grassroots criticism amongst Tatarstan's Muslims. Contemporary Islam. https://doi.org/10.1007/s11562-018-0428-8.

Bobrovnikov, V. (2011). From collective farm to Islamic museum? Deconstructing the narrative of highlander traditions in Dagestan. In exploring the edge of empire soviet era anthropology in the Caucasus and Central Asia. In F. Mühlfried \& S. Sokolovskiy (Eds.), Exploring the Edge of Empire: Soviet Era Anthropology in the Caucasus and Central Asia. Reihe: Halle studies in the anthropology of Eurasia (pp. 99-119).

Brubaker, R. (2004). Ethnicity without groups. In Ethnicity without groups. Cambridge: Harvard University Press.

Charles Hirschkind's commentary on everyday Islam curated collection (2014). Curated Collections, Cultural Anthropology website, https:/culanth.org/curated_collections/19-everyday-islam/discussions/18-charleshirschkind-s-commentary-on-everyday-islam-curated-collection. Accessed 14 Dec 2017.

Deeb, L. (2015). Thinking piety and the everyday together: A response to Fadil and Fernando. HAU: Journal of Ethnographic Theory, 5(2), 93-96.

Di Puppo, L. (2018). False signposts and high climbing. The search for a localised Islamic orthodoxy in Russia. Anthropological Journal of European Cultures, 27(2018), 99-104. https://doi.org/10.3167 /ajec.2018.270115.

Di Puppo, L. \& Schmoller, J. (2019). Here or elsewhere: Sufism and traditional Islam in Russia's Volga-Ural region. Contemporary Islam. https://doi.org/10.1007/s11562-018-00434-3.

Fadil, N., \& Fernando, M. (2015). Rediscovering the "everyday" Muslim: Notes on an anthropological divide. HAU: Journal of Ethnographic Theory, 5(2), 59-88.

Falkowski, M., Marszewski, M. (2010). Kaukaskie „terytoria plemienne”. Kaukaz Północny - cywilizacyjnie obca enklawa w granicach Rosji. Prace OSW, 34, http://www.osw.waw.pl/sites/default/files/PRACE_34. pdf. Accessed Jun 2018.

Gammer, M. (2002). Walking the tightrope between nationalism(s) and Islam(s): The case of Daghestan. Central Asian Survey, 21(2), 133-142.

Gammer, M. (ed.) (2009). Islam and Sufism in Daghestan, Helsinki: Academia Scientiarum Fennica.

Gordon H. (2011). Trends in jihadist violence in Russia during 2010 in statistics. Islam, Islamism and politics in Eurasia report. Monterey Institute for International Studies.

Gould, R. (2011). The modernity of premodern Islam in contemporary Daghestan. Contemporary Islam: Dynamics of Muslim Life, 5(2), 161-183 https://doi.org/10.2139/ssrn.1729601. Accessed 13 March 2018.

Gould, R. (2015). Why Daghestan is good to think: Moshe Gammer, Daghestan, and global Islamic history. In M. Gammer (Ed.), Written Culture in Daghestan (pp. 17-40). Helsinki: Annales Academiae Scientiarum Fennicae.

Hannerz, U. (2012). In A.C.G.M. Robben i J. A. Sluka (Ed.), Ethnographic Fieldwork: An Anthropological Reader Being there - And there - And there!: Reflections on multi-site ethnography. New Jersey: WileyBlackwell Anthologies in Social and Cultural Anthropology.

Jourde, C. (2009). The ethnographic sensibility: Overlooked authoritarian dynamics and Islamic ambivalences in West Africa. In E. Schatz (Ed.), Political ethnography: What immersion contributes to the study of power (pp. 213-214). Chicago: The University of Chicago Press.

Kaliszewska, I. (2015). Daghestani experiences of the state. In S. Voell \& I. Kaliszewska (Eds.), State and legal practice in the Caucasus. Anthropological perspectives on state and law (pp. 113-133). Farnham: Ashgate. 
Kaliszewska, I. (2016). Za Putina i za szarijat. Dagestańscy muzutmanie o Rosji i państwie islamskim. Warsaw: Warsaw University Press.

Kaliszewska, I., \& Voell, S. (2015). Pluralism, tradition and perspectives on the state in the Caucasus: Introduction. In I. Kaliszewska \& S. Voell (Eds.), State and legal practice in the Caucasus. Anthropological perspectives on state and law. Farnham: Ashgate.

Karpov, J. (2010). The Daghestani Mountain village. From the traditional Jamaat to its present social character. Anthropology \& Archeology of Eurasia, 48(4), 12-88.

Karpov, J., Kapustina J. (2011). Gorcy posle gor: Migracionnyje protsessi w Dagestanie w XX I w nachale XXI viekov, ikh socialniye i etnokulturniye posledstviya i perspektivy. Sankt Petersburg: Peterburgskoye Vostokovedeniye.

Knysh, A. (2007). Contextualizing the Salafi - Sufi conflict (from the northern Caucasus to Hadramawt). Middle Eastern Studies, 43, 503-530. https://doi.org/10.1080/00263200701348847.

Kvedaravicius, M. (2018). Carnal legalities: affective lives within zones of counter-terrorism operation. Subjectivity., 11, 339-356. https://doi.org/10.1057/s41286-018-0060-3.

Ledeneva, A. (2013). Can Russia Modernise? Sistema, Power Networks and Informal Governance. Cambrige: Cambridge Univeristy Press.

Malashenko, A. (2014). Islam in Russia. Changes in the Kremlin's politics. Russia in Global Affairs. 3/2014.

Mamdani, M. B. (2002). Good Muslim, bad Muslim: A political perspective on culture and terrorism. American Anthropologist, 104(3), 766-775. https://doi.org/10.1525/aa.2002.104.3.766.

Marcus, G. (1995). Ethnography in/of the world system: The emergence of multi-sited ethnography. Annual Review of Anthropology, 24, 95-117.

Marsden, M. (2005). Living Islam: Muslim religious experience in Pakistan's North-West Frontier. Cambridge: Cambridge University Press.

Marszewski, M. (2007). Środkowoazjatycki wahhabizm, http://www.etnologia. pl/swiat/teksty/srodkowoazjatycki-wahhabizm.php. Accessed 30 March 2011.

Moore, C. (2015). Foreign bodies: Transnational activism, the insurgency in the North Caucasus and "beyond". Terrorism and Political Violence., 27(3), 395-415.

Omelchenko, E., \& Sabirova, G. (2003). Islam and the search for identity. In H. Pilkington \& G. Yemelianova (Eds.), Islam in post-soviet Russia - Public and private faces. London: Routledge.

Osella, F., \& Soares, B. (2009). Islam, politics, anthropology. The Journal of the Royal Anthropological Institute, $15(1), 1-23$.

Pilkington, H., \& Yemelianova, G. (2003). Introduction. In H. Pilkington \& G. Yemelianowa (Eds.), Islam in post-soviet Russia. Public and private faces. London: Routledge.

Raubisko, I. (2009). Proper 'traditional' versus dangerous 'new': Religious ideology and idiosyncratic Islamic practices in post-soviet Chechnya. Journal of the Anthropological Society of Oxford, 1, http://www.isca. ox.ac.uk/fileadmin/ISCA/JASO/raubisko.pdf. Accessed Jun 2018.

Raubisko, I. (2011). Life in a negative - Positive space: Moral transformations in post-war Chechnya [unpublished PhD thesis]. University of Oxford.

Schielke, S. (2009). Being good in Ramadan: ambivalence, fragmentation and the moral self in the lives of young Egyptians. The Journal of the Royal Anthropological Institute, 15, S24-S40.

Schielke S. (2010). Second Thoughts about the Anthropology of Islam, or how to make Sense of Grand Schemes in Everyday Life. ZMO working papers. Vol. 2 (2010).

Schielke, S. (2018). Islam. In The Cambridge Encyclopedia of Anthropology (eds) F. Stein, S. Lazar, M. Candea, H. Diemberger, J. Robbins, A. Sanchez \& R. Stasch. https://doi.org/10.29164/18islam.

Sokolov D. (2017). Islam protiv soslovi i nomenklatury: konstruirovaniye novykh socialnykh prostranstv v Dagestanie. In Kavkazke lokalnye soobshchestva v globalnom mire: opyt izuczeniya politiczeskoi socialnoi I religioznoi transformatii. Izdatelski dom Branko.

Vicini, F. (2017). "Do not cross your legs" Islamic sociability, reciprocity and brotherhood in Turkey. SocArXiv. March 9. https://doi.org/10.31235/osf.io/r3d5m.

Ware, R. B., \& Kisriev, E. (2000). Ethnic parity and democratic pluralism in Dagestan: A Consociational approach. Europe-Asia Studies, 53(1), 105-131.

Ware, R. B., \& Kisriev, E. (2009). Dagestan: Russian hegemony and Islamic resistance in the North Caucasus. New York: Sharpe.

Yarlykapov, A. (2008). Islam u stiepnikh nogaycev. Moscow: IEA, RAN.

Yurchak, A. (2006). Everything was forever until it was no more: The last soviet generation. Princeton: Princeton University Press.

Publisher's note Springer Nature remains neutral with regard to jurisdictional claims in published maps and institutional affiliations. 